\title{
The Effect of Leadership on Employee Performance with Total Quality Management (TQM) as a Mediating Variable in Indonesian Petroleum Companies: A Case Study
}

\author{
Wagimin $^{1,2}$, Elisa Kusrini ${ }^{3 *}$, Juhary Ali ${ }^{1}$, Vembri Noor Helia ${ }^{3}$ \\ ${ }^{1}$ Asia e University, \\ Sultan Sulaiman Street, Kampung Attap, Kuala Lumpur, MALAYSIA \\ ${ }^{2}$ Balikpapan University, Balikpapan, Indonesia, \\ Pupuk Raya Street, Gunung Bahagia, Kalimantan Timur, 76114, INDONESIA \\ ${ }^{3}$ Faculty of Technology Industry, \\ Universitas Islam Indonesia, Yogyakarta, 55584, INDONESIA
}

DOI: https://doi.org/10.30880/ijie.2019.11.05.023

Received 25 April 2019; Accepted 08 September 2019; Available online 10 September 2019

\begin{abstract}
The score of employeesee performance of a petroleum company, for the last few years' achievement, have not yet met a significant increase. There is also a relationship between the organizational strategy, the Total Quality Management (TQM), and the organizational performance, with the mediating rules of TQM. This research is to identify and measure the level of factors that influence the effectiveness of work performance of employees who work in petroleum companies by identifying variable relationships including transformational leadership, transactional leadership, and TQM. This paper aims to determine the relationship between the variables mentioned above and the performance of employees in the oil and gas industry in Balikpapan Indonesia as samples using data from 250 employees. Analysis of the study using multivariate namely Structural Equation Modeling (SEM). The result shows that transformation leadership has positive effects on total quality management and employee performance. Second, transactional leadership has positive effects on total quality management and employee performance. Third, total quality management has positive effects on employee performance. Fourth, total quality management can mediate the indirect influence of transformational leadership on employee performance. Fifth, total quality management can mediate the indirect influence of transactional leadership on employee performance.
\end{abstract}

Keywords:Leadership, Total Quality Management, Employee performance, Structural Equation Modeling

\section{Introduction}

The current system, automation has penetrated into all fields such as data mining, leadership, and others [1]. In this globalization era where competitions are increasing, effective leadership is needed. A company-performancemeasurement method not only based on the results but also the process in order to make a comprehensive measurement. Leadership is an influence, as art or process influences other people, so they struggle towards mutual achievement, voluntarily and passionately [2]. The leadership from management to employees is linked to the level of performance level [3]. In the same line, the success of an institution or company only depends on the employees ${ }^{\text {ee }}$ performance and leadership. On the part of the employees, their tireless efforts, perseverance, and efficiency, inleading to their desired goals, are the several of the leadership styles [4]. The transformational and transactional leadership are the most distinguished among these styles. 
In oil and gas companies, quality has become one of the most important competitive strategic tools. It is the key to develop product and service that support sustainable success. As the competition and change are increasing in the business world, we should have a better understanding of quality. The worry of quality affects the strong organization in every competitive environment. Therefore, the top management needs to understand and apply the quality philosophy to achieve a high level of performance in product and processto face the challenge of the new global competition. There is an increasing focus on the quality of the entire world. A company must be aware of how important the quality system.Methods that can be used in quality control from Taguchi method by selecting the appropriate process parameters in many sectors [5-7] to Total Quality Management.

Total Quality Management (TQM) development has become a major business strategy in 1990. The TQM evolution becomes all management philosophies that sharply penetrated through the works of [8]. Many advantages of implementing TQM, such as scrap reduction [9], Many TQM-based have failed to show they are significant competitive in business performance. Many reasons for the lack of success caused by the lack of familiarity and attention to the success of determinant factors in implementing Total Quality Management. Therefore, the company needs to understand the TQM for the successful implementation of TQM [10]. Presently, TQM is a management philosophy to improve organizational competitiveness and the effectiveness of developing empirical searches in the future. Total Quality Management (TQM) is a technique often used by the good organization engaged in services and manufacturing, even in Small and Medium Enterprises [11] in order to help the customer satisfaction improvement, employee satisfaction, and productivity. In this company and several companies, such as Pars Oil and Gas Company, implementing Total Quality Management based on the Malcolm Baldrige model [12]. There is also a relationship between the organizational strategy, the TQM, and the organizational performance, with the mediating rules of TQM [13].

The score of employees ${ }^{\text {ee }}$ performance of a petroleum company, for the last few years' achievements, have not yet met a significant increase; even the 2010-2016 score of employees ${ }^{\text {ee }}$ performance had decreased to boost the score achievement towards a world-class company. Employees ${ }^{\text {ee }}$ performance is a resource in an organization; therefore they need to be properly trained and developed, to achieve organizational goal and expectation [14]. Moreover, continuous improvement is needed to improve quality, for example in industrial control [15].The initial development of the HRM (Human Resource Management) concept is based on the effective use of people, and to treat it as a resource leading to the business strategy realization and organizational goal [16].

A transformational leader has the charismatic abilities, induces the moral values, and tries to develop the employees' abilities. This leadership provides a kind of vision that increases the work potential and the followers/employees ${ }^{e e}$ commitment to achieving the high-valued tasks that produce the maximum output [17]. A transactional leader follows the style by applying rules and regulations, assigning authority letters, regulating and focusing on a specific goal, directing employees to achieve predetermined tasks [18]. TQM is a management philosophy that strives to improve the product quality and processes, continuously, to achieve customer satisfaction through a quality-driven strategy.

Improving employee performance depends on the leader. The centralized role of leadership that has prominent credibility is needed [3]. The leader of this category always pursues democratically and believes to solve every problem in the organization in accordance with the employees" popular will. Diagnostic skills that leaders have come from internally or through experience are needed to solve individual problems or with the whole organization [19]. The employees' performance is directly proportional to leadership effectiveness. In the same line, the success of these institutions depends only on the employee's performance and leadership. The result of various leadership styles is shown by employees' efforts in the form of perseverance and efficiency that aim at the desired goals [4].

The relationship between different leadership styles and TQM practice does not also seem to be clearly known between the gas and oil processing companies. Therefore, this research aims to determine the impact of different leadership styles on TQM practice in Indonesian Petroleum Company using SEM (Structural Equation Modeling). SEM is widely used in manufacturing companies, for example, to find out the relationship between transactional leadership and unity in the company and transformational behavior in relation to external supply chain partners [20]. Meanwhile, it is also used in service companies, such as to find out the application of technology in hospital [21]. TQM is projected as a total effort of a company (involving management, employees/non-management, suppliers, and customers) that aims to continuously improve the quality of products/services to achieve the customer satisfaction [22]. This research shows that the existing primary TQM components have been truly used and validated in most companies. Previous researches argue that leadership styles giving an important impact on improving TQM practices [23]. Therefore, it will be interesting to look into the different leadership styles and the influence ofTQM practices.

This paper is organized as follows. First, discussing the literature review on the measurement of the leadership style, the TQM, and the employees' performance on the introduction. Secondly, the model development that will be used later to identify the presented key indicators. Furthermore, the proposed key indicator is validated based on the employees' behavior of a Petroleum company in Indonesia. Finally, the conclusion for the key indicators of the TQM 
leadership and the performance, and the relationships occurring between the leadership, the TQM, and the employees' performance, by using the Structural Equation Modeling (SEM).

\section{Methodology}

\subsection{Hypothesis}

This research hypothesis is the transformational leadership, transactional leadership, TQM, and the employee's performance as a conceptual model of this study as shown in Fig 1. The hypothesis model consists of three latent variables and 22 indicators. By referring to the hypothesis and the frameworks of the models constructed in this research in Table 1, then the SEM analysis model specification constructed in this research is shown in Fig 2 . The descriptions of each variable and indicator from Table 1 and Figure 2 are: (1) X1: Transformational Leadership, LTF1: Idealized influence (Charismatic), LTF2: Inspirational and Motivation, LTF3: Intellectual Stimulation, LTF4: Individualized Consideration; (2) X2: Transactional Leadership, LTS1: Contingent reward, LTS2: Active management by exception, LTS3: Passive management by exception, LTS4: Laissez-fair; (3) M (Mediating/Intervening), TQM1: Focus on customers, TQM2: Obsession with quality, TQM3: Scientific approach, TQM4: Employees Empowerment, TQM5: Long-term commitment, TQM6: Team cooperation, TQM7: Education and training, TQM8: Controlled freedom, TQM9: One goal, TQM10: Employees involvement and empowerment; (4) Y: Employees' performance, PERF1: Financial factor, PERF2: Physical factor, PERF3: Social factor, PERF4: Psychological factor.

Table 1 - Hypothesis Formulation.

\begin{tabular}{ll}
\hline & \multicolumn{1}{c}{ Hypothesis } \\
\hline H1 & The Transformational Leadership has a positive and significant effect on TQM \\
H2 & The Transactional leadership has a positive and significant effect on TQM \\
H3 & The Transformational Leadership has a positive and significant effect on Employees' Performance \\
H4 & The Transactional Leadership has a positive and significant effect on Employees' performance \\
H5 & The TQM has a positive and significant effect on employees' performance \\
\hline
\end{tabular}

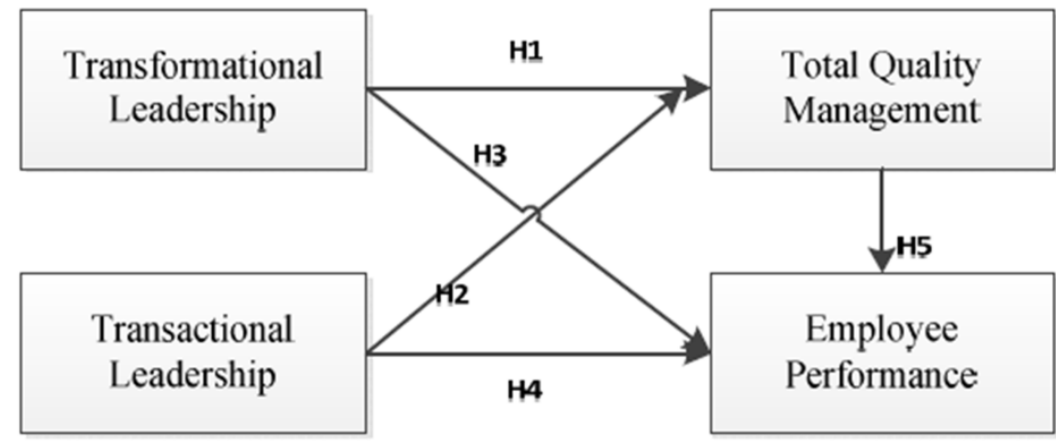

Fig. 1 - Conceptual Model of This Study.

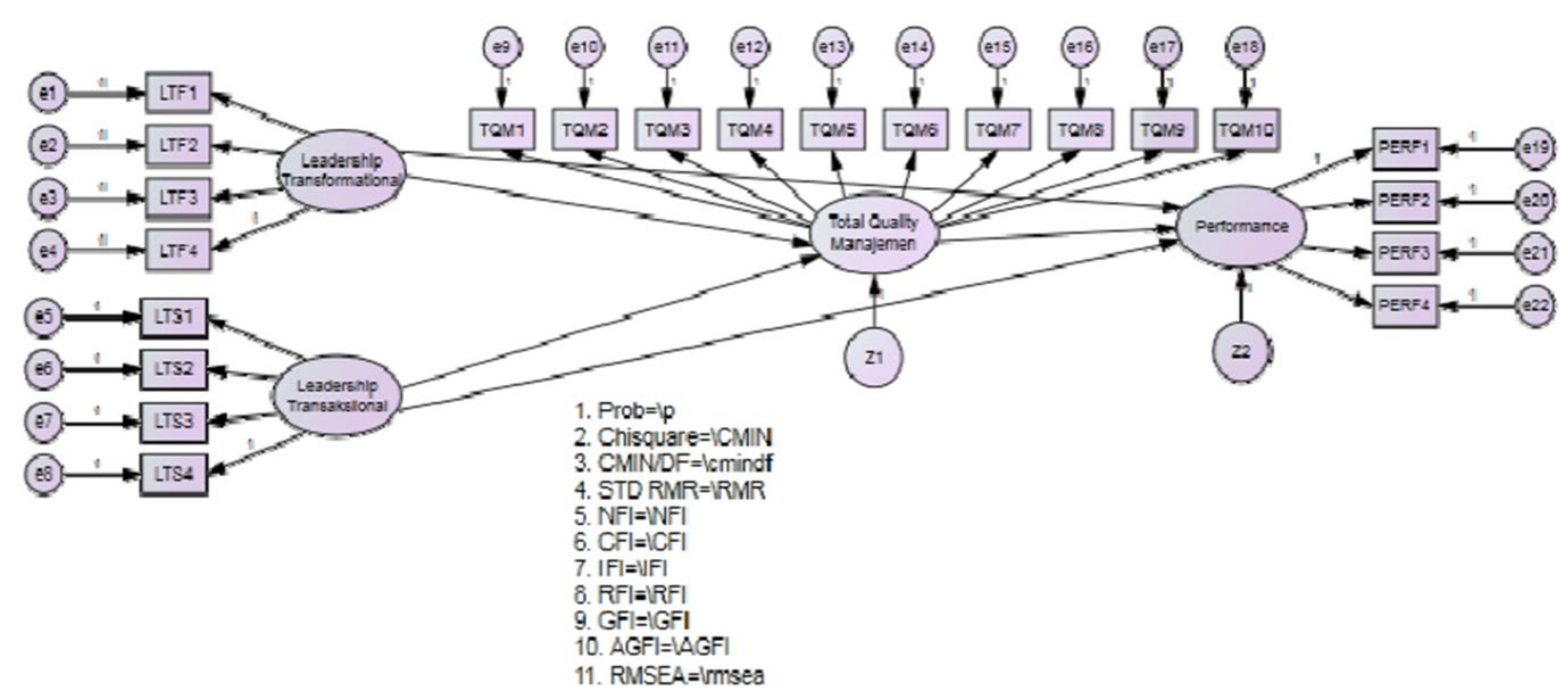




\subsection{Sample and Population}

Fig. 2 - Full specification of structural basic model.

This research uses 250 respondents with a total of 250 questionnaires distributed to 12 departments, which already have ISO (International Standardization of Organization) certified or SNI (Indonesian National Standard). They are the departments of Operation and Manufacturing Function, Engineering and Development, Reality Function, Procurement Function, Health, Safety, Environment Functions, General Affairs Functions, Human Resource Area/Business Partner Functions, Financial Functions, Information Technology, and OPI. The population in this research is the employees of those 12 departments. The questionnaires are distributed to the employees of the middle management level and the low management level. The questionnaire contains a construction measurement model and indicator, consisting of 22 indicators that grouped into four variables, which are the transformational leadership (4 indicators), the transactional leadership (4 indicators), the TQM (10 indicators), and the employees' performance (4 indicators).

The five-point Likert Scale starting from 1-5 (ranging from strongly agree to strongly disagree) is used to indicate the level of agreement for each series of statements in this questionnaire. Some statistical tests and analysis, confirmation analysis, descriptive analysis, correlation, multiple correlations, analysis of Structural Equation Models, are carried out using AMOS 22 software. The steps in the analysis are as follows [21]: 1. The development of theorybased models, 2. The development of flowcharts, 3. The selection of input data and estimation techniques, 4 . The evaluation of model identification, 5. The Assumption Model Evaluation and model suitability, 6. The interpretation and model modification.

\section{Results and Discussions}

\subsection{Characteristic of Respondent}

Characteristics of the respondents who completed a questionnaire in this study can be described as follows. Most respondents are male (63\%). Most respondents had ages between 21-30 years old (81.5\%); only $16.5 \%$ of respondent had ages between 31-40 years old and respondent had ages between 41-50 years old only 2\%. As much as $72.5 \%$ of respondents have been joined with the company for $1-5$ years and $27.5 \%$ of respondents have been joined with the company for 6-10 years. Out of 200 respondents, $52.5 \%$ of respondent have managerial positions and $47.5 \%$ of respondent have a non-managerial position.

\subsection{Structural Model and Basic SEM Assumptions}

Model in Fig 3 is the form of the model to be used in SEM study. There are some assumptions regarding SEM, such as sample size, normal distribution, outliers/extreme data, and multicollinearity data. SEM has the ability to model complex relationships between multivariate data. The sample size is an important (but unfortunately underemphasized) issue. Two popular assumptions are that you need more than 200 observations, or at least 50 more than 8 times the number of variables in the model. The larger sample size is always desired for SEM [24]. This study uses 250 participants that were randomly selected from the employee. So, this study has been fulfilled the assumptions regarding sample size.

This study also has been fulfilled the assumption about the normal distribution of their data. The data used in this study have normally distributed as indicated by the value of CR (Critical Ratio) Kurtosis and CR Skewness which were in the range between -2.580 until 2.580. After 4 outlier data are deleted from the model, the data is tested for normality again to find out the new data distribution. Thus, the next analysis will be carried out by using only 246 data.

Multicollinearity test is done by looking at the correlation value between exogenous variables. The model is declared free from multicollinearity if the correlation value between exogenous variables is $<0.9$. The multicollinearity test results show that the whole correlation value between exogenous variables is $<0.9$, which means there is no multicollinearity in the model.

\subsection{Confirmatory Factor Analysis}

Confirmatory Factor Analysis is used to test whether measures of a construct are consistent with a researcher's understanding of the nature of that construct (or factor). Four criteria in this study are used as summarized in Table 2. The first criterion is RMSEA (root mean square error of approximation). The RMSEA is acceptable or good when the value is less than 0.080 . The second criterion is GFI (goodness-of-fit index). The GFI is acceptable or good when the value greater than 0.900 . Although in this study, the value of GFI less than 0.900 , it does not necessarily mean that the model has a poor fit because the GFI is scaled between 0 and 1; higher values indicating a better model fit. The third criterion is RMR (root mean square residual). RMR is the square root of the mean of the squared discrepancies between the implied and observed covariance matrices. It is used to compare the fit of two different models with the same data. 
The RMR is acceptable or good when the value less than 0.050. The last criterion is CMIN/DF (chi-square fit index divided by degrees of freedom). The value of CMIN/DF in the range of 2 to 1 or 3 to 1 indicates an acceptable fit between the hypothetical model and the sample data.

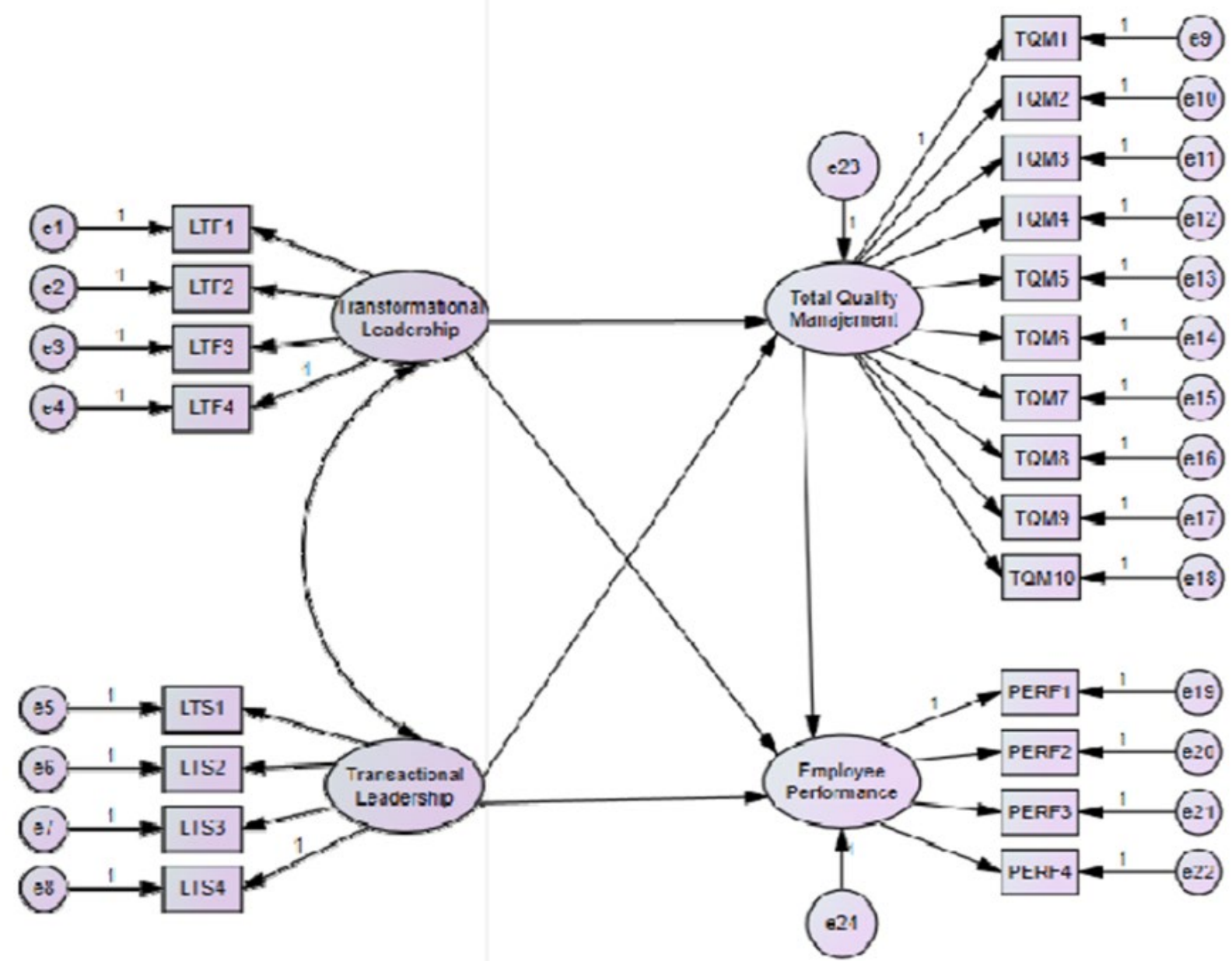

Fig.3 - Specification of SEM model.

Table 2 - Result of Goodness of fit model test.

\begin{tabular}{lccccccc}
\hline \multirow{2}{*}{ Criteria } & \multirow{2}{*}{ Cut Value } & \multicolumn{2}{c}{ Exogenous Model } & \multicolumn{2}{c}{ Endogenous Model } & \multicolumn{2}{c}{ Full Model } \\
\cline { 3 - 7 } & & Value & Result & Value & Result & Value & Result \\
\hline RMSEA & $\leq 0.08$ & 0.041 & Good & 0.029 & Good & 0.024 & Good \\
GFI & $\geq 0.90$ & 0.976 & Good & 0.952 & Good & 0.927 & Good \\
RMR & $\leq 0.05$ & 0.036 & Good & 0.016 & Good & 0.028 & Good \\
CMIN/DF & $1 \leq \mathrm{X} \leq 2$ or $1 \leq \mathrm{x} \leq 3$ & 1.412 & Good & 1.212 & Good & 1.143 & Good \\
\hline
\end{tabular}

\subsection{Validity and Reliability Test}

To test the validity of questionnaire items, this study used a standardized loading factor, which is more than 0.5 [25]. The result showed that all items which belong to all variable were valid. Next, the internal reliability of the items was verified by Composite Reliability (CR) and Average Variance Extracted (AVE) value. In this literature [25] suggested that the value of AVE must be higher than 0.5 and the value of CR must be higher than 0.7 . Based on the results of the value calculation of CR and AVE, all of the variables already have values above 0.5 AVE and CR above 0.7. Thus, it can be concluded that the constructs were therefore deemed to have adequate reliability.

\subsection{Hypothesis Test}

The results of testing the hypothesis are presented in Table 3: (i) The Transformational Leadership has a positive and significant effect on TQM (cr or critical ratio $=12.027, \mathrm{P}<0.05$ ); so hypothesis 1 was supported;(ii) The Transactional leadership has a positive and significant effect on TQM ( $\mathrm{cr}=2.691, \mathrm{P}<0.05$ ), so hypothesis 2 was supported; (iii) The Transformational Leadership has a positive and significant effect on Employees Performance $(\mathrm{cr}=$ 2.690, $\mathrm{P}<0.05$ ); so hypothesis 3 was supported; (iv) The Transactional Leadership has a positive and significant effect 
on Employees performance ( $\mathrm{cr}=2.057, \mathrm{P}<0.05)$, so hypothesis 4 was supported; and $(\mathrm{v})$ The TQM has a positive and significant effect on employees performance $(\mathrm{cr}=11.379, \mathrm{P}<0.05)$ so hypothesis 5 was supported. Fig 4 shows the result of SEM model estimate.

Table 3 - Result of Testing Hypothesis.

\begin{tabular}{|c|c|c|c|c|}
\hline Hypothesis & $\begin{array}{c}\text { Standardized } \\
\text { Regression Weight }\end{array}$ & cr & $\mathbf{P}$ & Result \\
\hline $\begin{array}{l}\text { The Transformational Leadership } \\
\text { hasapositive and significant effect on } \\
\text { TQM }\end{array}$ & 0.757 & 12.027 & $* * *$ & Accepted \\
\hline $\begin{array}{l}\text { The Transactional leadership has } \\
\text { apositiveand significant effect on TQM }\end{array}$ & 0.140 & 2.691 & 0.007 & Accepted \\
\hline $\begin{array}{l}\text { The Transformational Leadership } \\
\text { has a positive and significant effect } \\
\text { onEmployeesPerformance }\end{array}$ & 0.144 & 2.690 & 0.007 & Accepted \\
\hline $\begin{array}{l}\text { The Transactional Leadership has a } \\
\text { positive and significant effect on } \\
\text { Employees performance }\end{array}$ & 0.071 & 2.057 & 0.040 & Accepted \\
\hline $\begin{array}{l}\text { The TQM has a positive and } \\
\text { significant effect on employees } \\
\text { performance }\end{array}$ & 0.788 & 11.379 & $* * *$ & Accepted \\
\hline
\end{tabular}

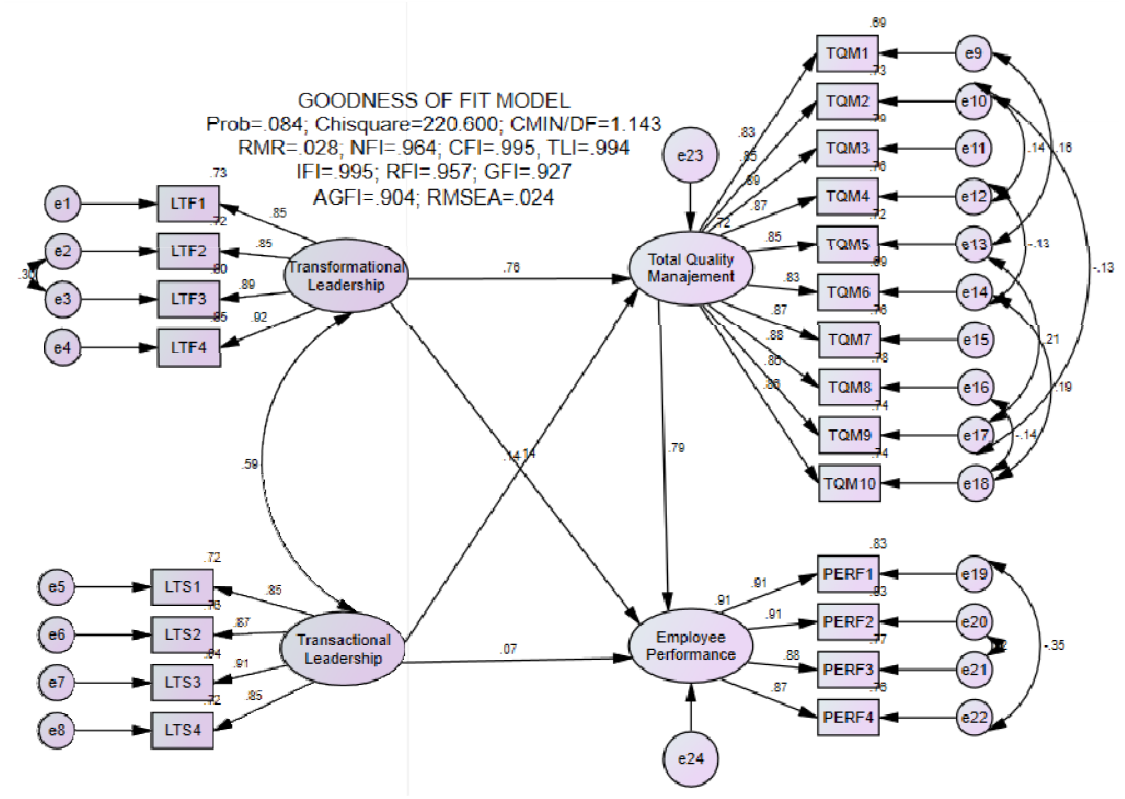

Fig. 4 - Result of SEM model estimated.

\subsection{Testing the mediating effect of TQM on the influence of Transformational and Transactional Leadership to employee performance}


The results of the analysis show that variable Transformational Leadership and Transactional Leadership have a significant effect on TQM and TQM has a positive and significant effect on performance. This indicates a role of TQM in variables mediate the indirect influence of Transformational Leadership and Transactional Leadership variables on performance. To test the significance of the role of TQM as a mediator, then performed by Sobel test. Based on the Sobel test results in Table 4, the results obtained that the TQM can mediate the variable indirect influence of Transformational leadership and Transactional leadership toward employee performance.

Table 4 - Result of Sobel Test.

\begin{tabular}{cccc}
\hline Path & T Statistic & p Value & Result \\
\hline TF - TQM - PERF & 8.852 & 0.000 & significant mediated \\
TS - TQM - PERF & 2.986 & 0.037 & significant mediated \\
\hline
\end{tabular}

\subsection{Research implication}

Research implications divided into three categories, which are policy implication, theoretical implication, and managerial implication. Policy Implication : (1) Performing the employees rotation and mutation periodically and evenly, generally; (2) The award from the leader to be even more for each class of employees; (3) Improving employees' welfare and providing special allowances for certain positions, prizes for the best employees in each section, and additional life/health insurance outside Health Insurance; (4) Working effectively and efficiently. Every job must be done on time so there are no delayed works. The employees need to be entrusted to do certain works independently and always improving the quality of work to achieve the target expectedly. The theoretical implications of this research are as follows: 1. Calculating the significance value relationship between variables using the AMOS application; 2. Creating a key performance indicator target; 3. Finding the gap contained in the implementation of TQM rules; 4. Formulating improvements by minimizing the gap by making the action items and achievement time target called the Specific, Measurable, Accountable, Relevant and Timeline (SMART).

Managerial Implications for Improving the Employees' Performance through TQM: 1. Caring for work, giving job responsibilities that are in line with interests, talents, abilities, and expertise; 2. Challenges at work, periodically rotating the works; 3. Learning new things at work, rotating the works regularly; 4 . The amount of income, adjusting the amount of income (allowances) with the workload, the level of difficulty, and the need for the Managerial Implications skills to Increase.

\section{Conclusions}

The newly produced model design supports [20] and [26] opinion, which defines the transformational leadership based on the influence and relationship of the leader with the followers or subordinates. Followers feel confident, admire, loyal, and respectful to their leader, and have high commitment and motivation for achievement and higher performance.

A transformational leader can motivate the followers in three ways [27] :(1) making them more aware of how important the job result is, (2) encouraging them to prioritize the organization or team rather than self-interest, and (3) activating their needs at a higher level. These indications also show that company employees, especially in this research, really expect the transformational leadership behavior from a General Manager or his supervisor, to increase the motivation of his subordinates to work. Subordinates still believe, admire, loyal, and respect their superiors or their leaders in their respective departments, although they are not the only media or means to increase their motivations.

The Transactional Leadership is very weak in the implementation of TQM, but still exists because it is an inseparable part. The results of this research indicate that Transactional Leadership has a positive and significant direct effect on TQM with the CR/T value of 2.691. The success of the implementation of TQM on the organizational commitments, which are the ability and willingness of the leadership, to carry out the basic tasks, and direct, influence, and encourage the subordinates to the integrated quality control program. To ensure the success of the implementation of TQM, the leadership must have an organizational commitment that is increasingly strong towards the achievement of TQM goals, which is the effort to satisfy the internal and external customers. This result is still consistent, that the transactional leader motivate their followers by exchanging rewards for works, or tasks that have been carried out, for example with awards, raising wages for followers who have performed high performances. But on the contrary, there will be given penalties (punishments) to the followers who have low performance or are below the target.

Total Quality Management (TQM) is considered as a very important factor for long-term success in a company. The TQM implementation has become an important aspect in improving organizational efficiency. The relationship between TQM and performance has used different types of performances. TQM focuses on the continuous improvement of processes in an organization. The motivation of the General Manager is to motivate, and the resource is to implement the TQM program. The application of TQM practices is associated with the improvement of 
organizational performance. The evidence from this research indicates the importance of developing an environment or cultural support to improve the results of TQM implementation performance, furthermore. If the employees do not feel any acknowledgment and support from the organization and from colleagues, then the implementation of the TQM program is not optimal.

From the results of this research, it can be concluded that transformation leadership has positive effects on total quality management and employee performance. Second, transactional leadership has positive effects on total quality management and employee performance. Third, total quality management has positive effects on employee performance. Fourth, total quality management can mediate the indirect influence of transformational leadership on employee performance. Fifth, total quality management can mediate the indirect influence of transactional leadership on employee performance. There are targets and improvements can be done by the management. In order to increase the employees' performance; important to note, that the leadership and the TQM are the top priorities. This can be done by giving rewards and punishments for the workers involved in the achievement of the Quality Assessment and performance in the oil and gas company.

\section{Acknowledgement}

This research was supported by Balikpapan University, Balikpapan, Indonesia and Universitas Islam Indonesia, Yogyakarta, Indonesia. This paper is part of the Ph.D. research in school of graduate studies, Asia e University.

\section{References}

[1] Triayudhi, A., and Fitri, I. (2018). Comparison of Parameter-Free Agglomerative Hierarchical Clustering Methods. ICIC Express Letters, 12(10), 973-980.

[2] Bass, B. (1985). Leadership and Performance Beyond Expectations. London: Collier Macmillan.

[3] Bass, B., Avolio, B., Jung, D., and Berson, Y. (2012). Predicting unit performance by assessing transformation and transactional leadership. Journal of Applied Psychology, 88(2), 207-218.

[4] Iqbal, N., Anwar, S., and Haider, N. (2015). Effect of leadership style on employee performance. Arabian Journal of Business and Management Review, 5(5), 1-6.

[5] Ismail, N. A., Ismail, M. I. S., Mohd Radzman, M. A., Mohd Ariffin, M. K. A., and As'arry, A. (2019). Parametric Optimization of Robot-based Single Point Incremental Forming Using Taguchi Method. International Journal of Integrated Engineering, 11(1), 217-224.

[6] Ahmad, S., Muhamad, N., Sahari, J., and Jamaludin, K. R., (2011). Optimisation of Sintering Factors of Titanium Foams Using Taguchi Method. International Journal of Integrated Engineering, 2(1).

[7] Ibrahim, M., Muhamad, N., Sulong, A., Jamaludin, K., Ahmad, S., and Nor, N. (2010). Single Performance Optimization of Micro Metal Injection Molding for the Highest Green Strength by Using Taguchi Method. International Journal of Integrated Engineering, 2(1), 1-6.

[8] Kumar, S., Mantha, S. S., and Kumar, A. (2009). Scrap reduction by using Total Quality Management tools. International Journal of Industrial Engineering, 16(4), 364-369.

[9] Juran, J., and Godfrey, A. B. (1999). Juran's Quality Handbook (fifth edition). New York: McGraw-Hill.

[10] Antony, J., Knowles, G., and Gosh, S. (2002). Critical success factors of TQM implementation in Hongkong industries. International Journal of Quality and Reability Management, 19(5), 551-556.

[11] Koc, T. (2011). The relationship between TQM and performance in small manufacturing enterprises: The mediation effect of failure. International Journal of Industrial Engineering, 18(4), 203-218.

[12] Yazdani, A., Soukhakian, M., and Mozaffari, M. (2013). Evaluation of critical success factors in Total Quality Management Implementation and Prioritization with AHP - case study: Pars Oil and Gas Company. European Online Journal of Natural and Social Science, 2(3), 1624-1633.

[13] Prajogo, D., and Sohal, A. (2004). The relationship between organization strategy, total quality management (TQM), and organization performance-the mediating role of TQM. European Journal of Operational Research, $168(1), 35-50$.

[14] Ismail, M., Nurdin, M., and Pura, H. H. (2018). Improving Quality and Work Quality at the 2019 World Skills Competition in Industrial Control. International Journal of Industrial Engineering, 5(3), 1-6.

[15] Brewster, C. (2007). Comparative HRM : European views and perspectives. The International Journal of Human Resource Management, 18(5), 769-787.

[16] Zhu, Y., Warner, M., and Rowley, C. (2007). Human Resource Management with Asian characteristic : a hybrid people- management system in East Asia. The International Journal of Human Resource Management, 18(5), 745768 .

[17] Birasnav, M., and Bienstock, J. (2019). Supply Chain Integration, Advanced Manufacturing Technology, and Strategic Leadership: An Empirical Study. Computers \& Industrial Engineering, 130, 142-157. 
[18] Helia, V. N., Asri, V. I., Kusrini, E., and Miranda, S. (2018). Modified technology acceptance model for hospital information system evaluation - a case study. MATEC Web of Conferences, 154, 01101:1-5.

[19] Pradeep, D., and Prabhu, N. (2011). The relationship between effective leadership and employee performance. International Conference on Advancements in Information Technology with Workshop Of ICBMG, 20, $198-207$.

[20] Avolio, B., and Bass, B. (2004). Multifactor leadership questionnaire: third edition. Manual and sampler set $\left(3^{\text {rd }}\right.$ ed.). CA: Mind Garden, Inc.

[21] Durga, D., and Prabhu, N. (2011). The relationship between effective leadership and employee performance. International Conference on Advancements in Information Technology, 20, 198-207.

[22] Dean Jr., J., and Bowen, D. (1994). Management theory and total quality: improving research and practice through theory development. Academy of Management Review, 19(3), 392-418.

[23] Ng, P., Yeow, J., Chin, T., Jee, K. S., and Chan, P. (2013). Leadership styles and their impact on TQM practices in Malaysian manufacturing firms. International Conference on Economics and Business Research, 1-6.

[24] Arbuckle, J. (2015). IBM SPSS and AMOS 22 User Guide.

[25] Ghozali, I. (2016). Aplikasi analisis multivariate dengan program IBM SPSS 23. Semarang: BPFE Universitas Diponegoro.

[26] Hughes, R., Ginnett, R., and Curphy, G. (2002). Leadership: Enhancing the Lessons of Experience (4 ${ }^{\text {th }}$ ed.). Boston: McGraw-Hill.

[27] G. Yukl (1998). Kepemimpinan dalam organisasi. Jakarta: Prenhallindo. 